\title{
CARE PRACTICES OF THE NURSE TO WOMEN IN CONJUGAL VIOLENCE SITUATION
}

\author{
Práticas de cuidado da(o) enfermeira(o) à mulher em situação de violência \\ conjugal
}

\section{Prácticas de cuidado de la enfermera a la mujer en situación de violencia conjugal}

Andréia Ribeiro Mota ${ }^{1}$, Juliana Costa Machado², Ninalva de Andrade Santos ${ }^{3}$, Aline Vieira Simões ${ }^{4}$,Vilara Maria Mesquita Mendes Pires ${ }^{5}$, Vanda Palmarella Rodrigues ${ }^{6}$

\section{Como citar este artigo:}

Mota AR, Machado JC, Santos NA, Simões AV, Pires VMMM, Rodrigues VP. Care practices of the nurse to women in conjugal violence situation. 2020 jan/dez; 12:840-849. DOI: http://dx.doi.org/0.9789/2175-5361. rpcfo.v12.7814.

\begin{abstract}
Objectives: To identify the conception of caring for women in situation of conjugal violence for the nurses of the Family Health Strategy and to describe the care developed to the woman in situation of conjugal violence by the nurse. Methods: A descriptive and qualitative study was carried out with 17 nurses from the Health Units of the family of a municipality in Bahia. The data were collected through semi-structured interviews and organized by the content analysis technique. Results: For the interviewed women the care of the woman in situation of conjugal violence involves reception and multiprofessional team work. Nurses welcome and seek to resolve women's grievances. However, women's silence, counter-referral and inadequate professional training were difficulties encountered. Conclusion: The professional qualification provides the resignification of the care to the woman in situation of conjugal violence, aiming at the integrality.
\end{abstract}

Descriptors: Violence against Women; Nursing care; Family Health Strategy.

\section{RESUMO}

Objetivos: identificar a concepção de cuidar da mulher em situação de violência conjugal para as(os) enfermeiras da Estratégia Saúde da Família e descrever o cuidado desenvolvido à mulher em situação de violência conjugal pela(o) enfermeira(o). Métodos: Pesquisa descritiva, qualitativa, realizada com 17 enfermeira(o)s das Unidades de Saúde da família de um município baiano. Os dados foram coletados por entrevistas semiestruturadas e organizados pela técnica de análise de conteúdo. Resultados: Para o(a)s entrevistado(a)s

1 Nursing Graduate, Specialist's Degree in Collective Health by the UESB.

2 Nursing Graduate, MSc in Nursing and Health by the UESB, PhD student enrolled in the Nursing Postgraduate Program at UESB, Assistant Professor at UESB.

3 Nursing Graduate, PhD in Nursing by the Universidade Federal da Bahia (UFBA), Adjunct Professor at UESB.

4 Nursing Graduate, MSc in Nursing and Health by the UESB, PhD student enrolled in the Nursing Postagraduate Program at Universidade do Estado do Rio de Janeiro (UERJ), Assistant Professor at UESB.

5 Nursing Graduate, PhD in Family and Society by the Universidade Católica do Salvador (UCSAL), Adjunct Professor at UESB.

6 Nursing Graduate, PhD in Nursing by the UFBA, Adjunct Professor at UESB. 
cuidar da mulher em situação de violência conjugal envolve acolhimento e trabalho em equipe multiprofissional. As(Os) enfermeiras(os) acolhem e buscam resolver as queixas da mulher. Entretanto, o silêncio da mulher, a contrarreferência e a capacitação profissional inadequada foram dificuldades encontradas. Conclusão: A capacitação profissional propicia a ressignificação do cuidado à mulher em situação de violência conjugal, visando à integralidade.

Descritores: Violência contra a Mulher; Cuidados de Enfermagem Estratégia Saúde da Família.

\section{RESUMÉN}

Objetivos: identificar la concepción de cuidar de la mujer en situación de violencia conyugal para las enfermeras de la Estrategia Salud de la Familia y describir el cuidado desarrollado a la mujer en situación de violencia conyugal por la enfermera. Métodos: Investigación descriptiva, cualitativa, realizada con 17 enfermeras (s) de las Unidades de Salud de la familia de un municipio baiano. Los datos fueron recolectados por entrevistas semiestructuradas y organizadas por la técnica de análisis de contenido. Resultados: Para el entrevistado (a) s cuidar a la mujer en situación de violencia conyugal implica acogida y trabajo en equipo multiprofesional Las enfermeras (as) acogen y buscan resolver las quejas de la mujer Sin embargo, el silencio de la mujer, la contrarreferencia y la capacitación profesional inadecuada fueron dificultades encontradas. Conclusión: La capacitación profesional propicia la resignificación del cuidado a la mujer en situación de violencia conyugal, buscando la integralidad.

Descriptores: Violencia contra la Mujer; Cuidados de Enfermería; Estrategia Salud de la Familia.

\section{INTRODUCTION}

Conjugal violence is the aggression that occurs between husband and wife who are legally married or living together in a stable union and may manifest itself in the domestic space or outside it. It may also occur between ex-spouses or ex-cohabitants, including relationships between brides or girlfriends. ${ }^{1}$

This problem is worrying because the external causes of death by violence are the third cause of death of fertile women, behind only neoplasms and diseases of the circulatory system. As an aggravating factor in this scenario, epidemiological data show that women under 30 years of age are more likely to suffer violence, with spouses, partners, boyfriends, and ex-boyfriends being the main responsible for the aggression. Physical violence is the most frequent ( $48.7 \%$ of the cases), and most assaults occur at home. ${ }^{2}$

The complexity of violence against women is a multidimensional phenomenon. In this sense, seeking to minimize these occurrences, a health care network for women suffering violence was established by the Brazilian Secretariat of Policies for Women, which constitutes a set of actions and services made available by different departments, mainly social assistance, justice and public security. These services' objective is to improve the quality of care, according to the principles of integrity and humanization, as well as efficient mechanisms of reference and counter-reference in cases of marital violence. ${ }^{3}$
In Brazil, nurses have stood out as a professional who acts directly or indirectly in the management and implementation of the Sistema Único de Saúde (SUS) [Brazilian Unified Health System]. In relation to the Ministerial Programs, they are members of the multiprofessional staff of the Family Health Strategy (FHS). For these professionals, the practice of caring requires a greater emphasis on relational technologies in order to allow a bilateral dialogue with people using health care services, allowing to know their expectations toward their practices. ${ }^{4}$ It is assumed that this strategic position tends to ease the identification of marital violence cases.

Marital violence stems from gender issues that determine unequal power relationships in patriarchal societies. Sex has a biological character; it cannot be changed. However, being a man or a woman are social and cultural constructions in which children are educated according to the expected behaviors for each gender, a fact that naturalizes male dominance and female subservience. In this context, it is necessary to reflect on the importance of promoting actions that contribute to the necessary change in gender relations so that men and women have the same rights. These are not only punitive actions because they focus on intervention strategy aiming at the cause of the problem. Health professionals working in FHS units, especially nurses, are fundamental to transform these discussions into health education actions, promoting the empowerment of women receiving care. ${ }^{5}$

Health care professionals should strategically put active listening into practice so that they can understand the conjugal contexts in which violence occurs. It is well known that women suffering violence are more vulnerable to social isolation and self-negation at work, which requires psychological support (in order to empower them to exercise control over their life) and social support, with qualification for the job market and opportunities to generate income and employment, glimpsing the possibility of leaving the violent relationship. ${ }^{6}$

Proactive and qualified care by nurses working in FHS units is important for the establishment of a bond of trust and for care free of prejudice and judgment. These considerations point out the need for spaces for discussion on the problem since the experience of marital violence is not always perceived by these professionals, which justifies this study.

This study was based on the following research questions: "What does caring for women suffering marital violence mean to FHS nurses?" and "How do FHS nurses deliver care for women suffering marital violence?"

To answer these questions, we identified and described the concept of caring for women suffering marital violence as perceived by nurses working in FHS units. 


\section{METHODS}

This descriptive research with a qualitative approach was carried out in a municipality from the Bahia State countryside, Brazil, which has 42 Family Health Units (FHUs): 17 located in the rural area and 25 in the urban area.

The inclusion criteria were as follows: FHUs having a complete nursing staff as recommended by the Ministry of Health (Brazil) and located in the urban area, at which one or two teams worked. The FHU in which one of the researchers worked was excluded.

The sample was composed of 17 FHUs located in the urban area of the municipality. Considering those FHUs, 14 had two teams and three had one team. In units with two teams, only the available nurse was interviewed.

Seventeen nurses participated in this study. The inclusion criterion was to work in the unit for at least six months and the exclusion criterion was to be absent from work due to vacation or medical leave.

The research project was approved by the Research Ethics Committee under the Certificado de Apresentação para Apreciação Ética (CAAE) [Certificate of Presentation for Ethical Appreciation] No. 79015517.6.0000.0055 and the Legal Opinion No. 2.416.808/2017. The ethical principles stated by Resolution No. 466/2012, which regulates studies with human beings, were strictly followed.

Privacy was guaranteed by labeling each participant using the letter $\mathrm{P}$ (participant) followed by a number that corresponded to the order in which the interview was conducted (for instance, $\mathrm{P} 1$ ).

Data were collected by using a semi-structured interview and a tape recorder from February to May 2018. The interviews were carried out in private locations of each FHU. The application of the instrument lasted 20 minutes on average. The instrument covered the following topics: conception of caring for women suffering marital violence; actions against marital violence; difficulties and facilitators found during the development of care practices for women suffering marital violence; and actions associated with the services integrating the network of attention to violence aiming at confronting marital violence.

The data were submitted to content analysis, a thematic modality that consists of the set of techniques of communication analysis carried out through systematic and objective procedures for describing the content of the messages. Content analysis has the following phases: pre-analysis, exploration of the material, and treatment of the data, inference and interpretation. ${ }^{7}$

After data treatment, the following categories emerged: "Caring for women suffering marital violence as perceived by nurses"; "Care practices by nurses for women suffering marital violence"; and "Difficulties and facilitators found by nurses during the development of care practices for women suffering marital violence".

\section{RESULTS}

Considering the 17 participants, 16 were female. The majority of the participants declared themselves to be brown-skinned (64.7\%), catholic (52.9\%), and married (64.7\%). The age range was $27-54$ years old. All of them had postgraduate degrees (Lato Sensu) in nursing. The period of professional experience varied from three to 30 years and the period of work in the FHS unit ranged from six months to 13 years. Of this total, $82.3 \%$ reported attending courses on marital violence.

\section{Caring for women suffering marital violence as perceived by nurses}

The nurses understood that reception is important for delivering care for women suffering marital violence, resulting in the development of sensitive listening.

I think it's important to care for her, to receive her well at the PSF [Programa Saúde da Família - Family Health Program] unit, it's important that we receive her because she's already suffering [...]. (P2)

While the health care unit has to receive them, listen to them, and guide them, not beyond physiological care related to attention [...]. (P7)

[...] the matter of reception, even embracing that woman, giving support to her, encouraging her to leave this environment, that she does not accept that situation [...]. (P12)

Nursing care is sensitive listening, receiving the woman so that she feels at ease to open up to you, often she hides the fact so that her husband couldn't be put into prison, because she doesn't work and needs to support her children, if you don't make her feel that she had a good reception [...]. (P17)

The work of the multiprofessional team was also highlighted by the participants' statements.

It's totally necessary a multiprofessional team [...] action of the psychologist of NASF [Núcleo de Apoio a Saúde da Família - Family Health Support Center]. (P3)

[...] my point is that the health care team we meet at the PSF isn't enough, because it involves other departments of the network, including the police depending on the case, regardless of who committed the violence, the CRAS 
[Centro de Referência de Assistência Social - Social Assistance Referral Center], also with Social Assistance [...] psychological assistance. (P11)

When asked about the concept of caring for women suffering marital violence, the nurses highlighted the inexistence of marital violence in the context of the FHS.

[...] many cases end up going unnoticed, many cases don't even come to our attention [...] it's in the meeting that we have to discuss everything [...] this matter of violence against women is a topic that hasn't been tackled much [...] because there have never been cases that could be brought by them [community health agents] in order to discuss them in a meeting [...]. (P1)

[...] we work with community health agents, and the one who knows the family best is the agent, the agents of my team, they haven't reported to me yet, look we have this case in the micro-area [...]. (P4)

Here in our practice, it's actually very unusual for a woman suffering violence, [...] in this period here of four years I have never seen any woman suffering violence. (P11)

Today in the unit that I work in will be four years [...] no case of violence has ever come to my attention from the team [...]. (P14)

\section{Care practices by nurses for women suffering marital violence}

Regarding the care practices for women suffering marital violence, the nurses indicated that they received these women, listened to them, supported them and resolved their complaints.

[...] I listened to her, I tried to resolve her complaint, her anguish, I talked to her, I received her [...]. (P1)

We receive sporadic cases from the community health agent, trying to welcome her, see her, and refer her to someone else in a way that doesn't invade her privacy. (P10)

Participants 6 and 15 reported cases of marital violence, although they emphasized that they do not always obtain the woman's authorization to fill out the notification form.

In the matter of marital violence we can observe, I will say in the matter of my work environment when a woman arrives with any type of complaint, often it's not only the violence [...] we already make the notification, she always instructing me to only make records, data to register [...] cases of violence, but this has no legal value in the sense of denunciation, this hasn't power of police for investigating cases [...] at least I have already filled out about four [...]. Two were brought by an agent, others were appointments [...] some don't allow me to fill out the notification form, there are many that I can't fill out and they say they don't want to talk at all because I think it will lead to something, they're afraid of their husband. (P6)

I notify everyone, even if they don't know, I refer them to CRAS, DEAM [Delegacia Especializada de Atendimento à Mulher - Women's Protection Police Station], when I can't get anything to convince them to see a psychologist. (P15)

Some interviewees mentioned the nurses' care practices for instruct women on be aware of their rights and seek the services provided by the attention network.

Thus, I have already referred her to the CRAV [Centro de Referência Albertina Vasconcelos - Albertina Vasconcelos Referral Center], and I have already instructed the woman to look for the Department, the DEAM. (P2)

Look I already had it in this unit that I'm currently working in, I had a situation of a homeless woman because she doesn't have a fixed residence [...] and she was stabbed on the hand, in fact, she sought the unit because of the vaccination that she went to the hospital and in the hospital, they advised that she should take tetanus vaccine and there she went to my room, I talked to her a little [...] So I followed all the guidelines related to what her right was [...] I talked to her, I instructed her in this matter a lot, but I believe that she didn't seek the service, I referred her to the CRAS. (P11)

[...] I consider this a difficult situation, because it involves a relationship between two people and there's also family issues and [...] what we can do is to keep giving instructions. (P4)

It is also highlighted the articulation established by the FHS nurses with the services of the attention network for women suffering conjugal violence.

[...] I needed the NASF psychologist to work with me, mainly the CRAS social worker [...] we needed the DEAM, [...] social worker who was with me to contact the family [...] we even asked for police escort, because her husband had to know nothing, because, she was afraid that he would know it and she had fear that he would kill her if he knew it, then she went with her children, so she has the issue of custody, she needed documents, lawyers from there, so it's a whole service network and I as a nurse couldn't see it and have the sensitivity to instruct 
her, not close my eyes, not pretend I didn't see it, but I needed a whole service network and this woman went to her family. (P3)

We take a representative of the service network to the health fair to raise awareness of women rights and strengthen the women's' self-esteem, in order for them not to be a hostage and strengthen this situation, the CRAV, for example during the Outubro Rosa [Pink October] campaign. (P10)

[...] she's referred to the DEAM, also to the violence reference posts, the CRAV, and depending on the situation, also if there's a child issue we also look for the Child Protection Council to help us, we do basically this [...] We refer her to the Police Station but there's no guarantee that she will go there, sometimes these patients disappear from the area, we don't know if she went there. (P6)

We have a very open relationship with the police chief, a judge who works on violence cases, we denounce anonymously cases that the neighbors bring to us, I ask a CRAS member to take a visit and see where the partner comes from. (P15)

[...] from the CRAS, mainly from the social worker in order to be able to work together here too, in the case of the DEAM, because they also provide all the support. (P3)

We partner with the NASF whenever necessary. (P10)

\section{Difficulties and facilitators found by nurses during the development of care practices for women suffering marital violence}

As facilitators to dealing with marital violence cases, the nurses highlighted the training of the team, the bond established with women and the good relation with the service network. However, they emphasized certain obstacles to the implementation of counter-reference.

The team here is well trained and this counts as a facilitator, the team is attentive and everyone makes the notification, the NASF also does. (P15)

[...] I think the bond we create counts as a facilitator in a sense, [...] but I think that the bond that we create here in the unit exists because these people are registered at this area, because these people are always here, being followed up by our team. (P13)
[...] the Women's Referral Center, so it was they [the team], for example, who gave all the support to us as I spoke throughout the phone call, passage [...], we got a certain place from the Department of Social Development of the municipality, which has resources so that she could be sent [...] the CRAV staff referred them to the Department of Social Development because its members are more used to working with it and got this resource. (P3)

We have a good relationship with the service network, all that is missing is feedback and if you don't get the referral [...] because they don't give this feedback. (P10)

The women's silence was the difficulty mentioned by most participants, which makes it difficult for FHS nurses to register the cases of marital violence.

[...] I think this issue of marital violence is very complicated, because first the women hide [...] they report that they suffered an accident and that it was this and that, but they never say that in fact, they suffered violence, so it is a bit complicated for us to work on this part [...]. (P1)

[...] one difficulty is that she trusts you and comes to you so that she can talk about the violence she has been suffering. (P2)

[...] the woman, she's afraid of being cared for, of speaking, first, she has the difficulty in realizing that violence exists because she tries her best to hide it. (P3)

I find this issue of violence very complicated, first for the patients themselves because they don't usually speak, they hide, they are ashamed, afraid, so they don't usually open up. (P5)

[...] the woman is ashamed to speak, sometimes she's afraid because of the issue of violence in the area here which is very risky, there are many cases of drug trafficking [...]. (P8)

The difficulty is that she doesn't open up, she hides it, if there's no way for her to open up, a relationship, she won't open up [...]. (P10)

[...] in relation to the care for this woman, it's sometimes very unclear, I have even observed, for example, signs and if I ask the woman what was the cause and such and, sometimes, she does not open up. (P13) 
The difficulty is that they seek us, we are also afraid of their partners because they are [drug] users, we take the most discreet approach possible. (P15)

The difficulty is that she doesn't open up to us. (P16)

Social vulnerability and fear of retaliation were pointed out by the interviewees as obstacles to identify cases of marital violence within micro-areas.

The biggest difficulty I encounter is because here is a peripheral neighborhood so I'm afraid, or rather, in fear, that we try to help and end up being targeted [...]. (P1)

[...] my difficulty is related to my situation, the neighborhood has very large social vulnerability, it's often difficult to understand this woman and often realize what is happening, many of them are already in custody, they are already in prison here in the area, there have been cases of serious violence when the spouse leaves the prison and finds out that she had a relationship while he was in prison, there are also several problems of this type that we don't know how to tackle. (P6)

Drug trafficking in some micro-areas has been identified as one of the reasons for concern and makes it difficult to identify cases of marital violence.

[...] usually, those working in PSF units covering violent areas are concerned about their own lives. (P5)

[...] but we don't know and I can't keep asking [...] our area is dangerous, an area of risk [...] the case here is very difficult, there are many good people, but there are drug dealers here, people that are associated with drug trafficking. (P12)

The reference and the counter-reference were other difficulties pointed out by the nurses working in association with the network of assistance to women suffering conjugal violence.

[...] in relation to counter-reference, it's not easy to work in association with the assistance network, even in relation to time, for example, we as an FHS professional [...] couldn't talk, so it was necessary to leave the shift here and go to the DEAM to talk, so I would have to change an entire agenda [...] we had to go there several times [...] At first we tried going to the CRAS [...] that would guide us and support us, but the CRAS did nothing, so that's why we end up tackling it, so we just informed the CRAS of this situation, and it did nothing, and we had to do it [...] working with the assistance network, it has to happen, if it doesn't happen we can't deal with this demand that is violence. (P3)

In fact, I informally refer her to the CRAV, but we don't have a very organized network, protocols, or an established flowchart. (P7)

Professional training was mentioned as an obstacle for professionals dealing with cases of marital violence.

First of all, we really didn't have that training. (P2)

[...] we never received practically anything, we don't know that this department exists, the CRAV for example, we know about the DEAM from the media like any other people, no meeting for erasing doubts took place, something like this in an official way that received some craft, something like this, no [...] I've never participated in anything in this sense, because I know that, there's what any other person in the community knows, nothing official came to us, as professionals we know nothing [...] I think it would be positive if we had a workshop, mainly a presentation, as in my case we work [...] in peripheral areas of extreme violence, would be interesting for us to learn to proceed, so that we can be trained more effectively. (P5)

Training, it's a topic that has received little attention, there's a great difficulty because of that. (P7)

Participating in the training on how to offer guidance and fill out the domestic violence notification form promoted by the Municipal Health Department was highlighted as a positive action for minimizing the occurrence of underreporting.

[...] I even remembered that we participated in training here in the Health Department that we even received a form for us to fill out related to this type of occurrence and notification [...]. We received the form here to be used when there is need [...] we don't have to intervene and I know that there's a government department, the CRAS, generally, they can, I mean, they can pay a visit, give guidance or some care related to it [...] and we as FHS workers won't intervene in this issue, understand? (P4)

[...] we did a training the information we gained was passed to the professionals, especially health agents during the team meeting, we talked to them about the notification form and the importance of knowing these cases, this information is being passed to the team members for them to act properly [...]. (P14) 


\section{DISCUSSION}

The results showed that the nurses consider the care for women suffering marital violence as a practice based on reception, active listening, bonding, which are actions that go beyond the biological aspect. This perspective focused on the subjectivity of the care praxis is fundamental for delivering complete care for women suffering marital violence.

Reception as a subjective dimension of the care allows forming a bond between the person delivering care and the one receiving it. This is in line with the Ministry of Health (Brazil), which considers reception as the act of recognizing whatever others say as a legitimate and unique health need. Reception is an important strategy for maintaining the relationship between teams/services and patients. As an important health care practice, reception is built in a collective way, based on the analysis of the work processes and has the objective of building relationships with trust and commitment, as well as forming bonds between teams and services, workers and teams, and users and their socio-affective network. ${ }^{8}$

The community health agents are important for the approach between service and customers. These professionals, who are part of the FHS multiprofessional team, have an important role in the implementation of prevention actions, investigation, identification, support and referral of women suffering marital violence. Furthermore, they can contribute to the development of coping strategies for dealing with each multifaceted family/case. This reality highlights the need to integrate permanent health education programs covering epidemiology, women's rights and support network available in all Brazilian federative units (Municipalities, States and the Union) for better professional performance so that the users' basic needs could be identified and minimized. ${ }^{9}$

The fragility of the attention network for women suffering violence is pointed out in some studies. One of them was carried out in a municipality of the northwestern region of the Rio Grande do Sul State in 2015, which pointed out that these services used no protocols and flowcharts and lacked coordinated work. Furthermore, the FHS professionals had little training on how to act in cases of violence against women. The absence of a reference and counter-reference system was identified as a limiting factor for acting properly. ${ }^{10}$

According to the participants, the isolated actions of the FHS team did not meet the needs of women suffering marital violence. It is noted that in some situations the nurses sought help from professionals of the NASF and CRAS so that psychologists and social workers could contribute to promoting caring actions since the specificities of each situation required several referrals and partnerships. The link between NASF and FHS is established based on the logic of co-responsibility through a matrix support relationship, and it is expected that this articulation will lead to constant communication, which means thinking about the NASF activities from the action planning to the execution of activities, which are the pedagogical character and the effective participation of the FHS team. ${ }^{11}$
In the daily life of the NASF teams, these interconnected actions occur mainly through referrals from the FHS teams, which reproduces a traditional logic in the health care system by establishing verticalized relationships of transfer of responsibility for dealing with the case. These relationships are caused by precarious communication between different hierarchical levels. In addition to maintaining the traditional system of reference and counter-reference that offers little results to the health care system, when there is some participation of the FHS team in the actions developed by the NASF team, this participation is restricted to operational issues, in other words, the FHS team makes it possible to schedule the location and time for executing the action, as well as when to publicize it. However, the FHS team remains absent at the time of executing it. ${ }^{11}$

Considering marital violence as a complex phenomenon, the need for integration and effective participation between NASF and FHS professionals since the planning of actions is highlighted. Consequently, it is necessary to meet the women's demands including biological, psychological, social, and spiritual aspects. This requires support from the other services that integrate the attention network.

In view of the high frequency of cases of marital/ domestic violence in Brazil, it is worth noting that most nurses were unaware of the occurrence of this problem at their workplace, did not address the problems concerning health care education and periodic planning during the meetings, and did not refer the problem to the community health agents claiming that the lack of knowledge of the cases is due to the fact that they did not talk about this demand during the team meetings. It is understood that, because the agents work in the field, they can identify the cases more frequently, but the whole health care team needs to be engaged in this process.

A study showed that women suffering violence are eager to receive humanized and qualified assistance. In this perspective, when considering health care services as part of a network of care for women suffering violence and professionals as co-responsible in this process, it is necessary to approach the life experience context to promote dialog, active listening and more familiar and less anonymous relationships, with care aiming at meeting the women's needs. ${ }^{12}$

In this sense, it is useful to recognize the actions by professionals toward women suffering violence, especially the actions of a nurse, as an interactive process that needs to be lived and shared, since this movement can materialize in important meanings for both the woman and the professional. Interaction transcends adherence of a service: it means establishing and strengthening a relationship of familiarity when providing subjective assistance to these women, seeking the resolution of their needs and demands, as well as developing strategies for their empowerment, promoting their access to justice and raising awareness about their rights. ${ }^{12}$

The professionals who provided assistance to women suffering violence, especially nurses, must consider the singularity of each case: being a woman (and experiencing 
unequal power relations caused by gender issues), having a daily relationship with the aggressor; and having a history of daily life marked by violence. Often, this situation that can be frequent leaves marks on the physical body or scars on the soul, which is silent suffering that can lead to physical and/or mental damage. ${ }^{13}$

Thus, it is urgent to re-signify the understanding of conjugal violence, implementing an action plan that is not restricted to biological aspects or merely technical procedures. The new paradigm demands that care should transcend historical, social, cultural, relational, economic, ethical and legal aspects in order to seek to establish relationships of familiarity and intersubjectivity with women in this situation. ${ }^{13}$

A study showed that, although FHS professionals have referred women suffering marital violence to the psychologist and social worker of the NASF, to the Referral Center, to the DEAM, to the Legal Medical Institute and to the hospital or maternity ward, most are unaware of the performance of these services. In this sense, it was identified that the lack of intersectoral coordination compromised the care for the woman. ${ }^{14}$

In this sense, it is important to emphasize that the referrals should not be restricted to the simple recommendation that these women should seek network services. Instead, they have to be instructed to seek the existing flowcharts so that the effective mechanisms of reference and counter-reference could be established by the effective coordination between all the services that form the attention network for women suffering marital violence.

In view of its daily care practice in the different health care services, nursing should seek to guide and lead women so that their needs could be received and resolved, offering assistance integrated to other services in an intersectoral manner, in addition to making the necessary referrals based on legislation on fighting violence, especially against women. ${ }^{13}$

A study has emphasized the importance of the maintenance of care for women suffering violence. Furthermore, it highlighted that the flowchart can represent the path of women and guide the organization of network care. In this perspective, there is a need to (re)build the network flowchart so that these women could receive assistance first from the health care and social assistance services, education and public security; Basic Health Units, FHS, hospitals, Emergency Care Units, offices, CRAS, Specialized Referral Center for Social Assistance, schools, $D E A M$ and police stations in general. In this task of collective construction of the proposed flowchart, the need to establish communication with other services and even institutional coordination between the Departments of Health and Social Assistance, DEAMs, Legal Medical Department, and school clinics was highlighted. It is necessary to define aspects that demand modification according to the possibilities of each service, which pointed out the need for professionals to interact, establish contact, communication, and gain knowledge of the different services. ${ }^{15}$
If the network is defined on the basis of a flowchart developed with the participation of the members of different services, it can promote the care offered to women suffering marital violence, making reference and counter-reference effective in practice and resignifying the integral care practices.

The need for building the network is a collective task, which needs to involve the services through dialogue and institutional definitions of the roles they can play within the network. The advance in the construction of a powerful network for the continuous care for women suffering violence requires involving different departments, especially the management, through affirmative actions, communication mechanisms and intersectoral coordination between the municipalities. ${ }^{15}$

The nurses highlighted the women's silence and reception at the unit, the coordination between network services and the need for professional training as difficulties in dealing with marital violence.

For most of the interviewees, the silence stems from the woman's fear of her partner. One of the nurses stated that these women usually need confidence to report the violence, as they usually hide or omit the real reason for being hurt.

A study showed that women suffering aggression avoid reporting the aggressor and isolate themselves, which makes them depend on the aggressor even more. In this way, the feeling of fear that paralyzes and prevents the woman from seeking help arises more often. In addition, women tend to soften the situation of violence because of factors such as fear, lack of information and awareness about what really constitutes violence, and the desire to believe that their partner is not so bad. ${ }^{16}$

The study participants considered fear to be dependent on the peripheral region. For them, the aggressors' criminal record (since they were ex-prisoners and/or drug dealers) hinders the identification of marital violence cases. This happens because there is the possibility of these women suffering retaliation from their aggressors or community members.

A study highlighted that violence is present in a variety of social contexts, especially in communities affected by drug trafficking, making the population live with frequent robbery and shooting. In this framework, FHS professionals expressed a variety of feelings because they could do nothing to help the women suffering violence, which produced a negative impact on the performance of these professionals in such adverse environments. ${ }^{17}$ It is understood that this situation tends to make it difficult to identify and manage cases of marital violence.

For the interviewees, there are difficulties related to the referrals to and coordination of the network. The professionals had little time to provide a referral, which is often a bureaucratic process and with no return. The participants recognized the need for coordinating the multiprofessional care with other services. However, they 
have expectations that there will be a network, a specialized service, that will receive women suffering violence. Nevertheless, little has been done toward this referral or the maintenance of care, which points to a discrete interaction and insertion of the health care services in the support network for women suffering marital violence. As for the existing services, they mentioned difficulties in providing follow-up care and communicating with each other.

One of the interviewees stated that the knowledge acquired came through the media, which is a worrying situation. The interviewees stated that they know the importance of training and that they would very much like to do it so that they could feel more prepared to deal with cases of marital violence.

Approaching violence cannot be limited to conceptual procedures such as the types of violence and signs to be observed by the FHS teams. For this, it is necessary to promote spaces for reflection on the practice, based on concrete cases attended to by the teams, considering dilemmas and the subjective and ethical aspects of the actions to be performed. Consequently, a multiprofessional reading of the situation through teamwork could be possible, with shared decisions and the constant reassessment of the choices made. ${ }^{18}$

The interviewees reported training in understanding the notification form, but they did not need to fill out these documents, demonstrating a lack of skill.

A study, which addressed the importance of compulsory notification of violence against women, highlighted that the FHS professionals do not make notifications of violent actions. Furthermore, one of the reasons associated with underreporting is the difficulty experienced by health care professionals when trying to identify the action because the subject is obscure. This difficulty may be associated with a lack of qualified education. The study also showed that there is no guarantee that a professional having a postgraduate degree will make notification of violence against women, suggesting that these postgraduate courses do not cover this subject or do it in a superficial way, sometimes focusing on the service flow provided for women suffering sexual violence. On the other hand, the health professionals mentioned that the subject is not discussed at their workplace. ${ }^{19}$

It is evident the need for both academic and professional training in order to instrumentalize health care teams, especially nurses, to act in the face of violence against women. In this perspective, higher education institutions need to promote discussions about this issue in order to enable the understanding of gender inequality, which favors violence in the relationships between men and women. The coordination between teaching and health care for training with an emphasis on making notifications and identifying violent actions enable health surveillance and the development of research and extension projects that make it possible to unveil and transform this reality. Some strategies aimed at training professionals for caring for women suffering violence can also be implemented. ${ }^{19}$

\section{CONCLUSIONS}

The nurses understood that the care for women suffering matrimonial violence must involve reception and multiprofessional teamwork despite their vulnerability due to working in peripheral neighborhoods, which seems to contribute to the invisibility of violence. The difficulty in recognizing cases of marital violence constitutes a serious public health problem.

The nurses received these women, supported them, guided them, sought to resolve their complaints, make notifications, and acted in coordination with some network services.

They considered the qualification of the team, the bond established with women suffering violence and the good relationship with the service network as facilitators. Nevertheless, they pointed out that there is still no counter reference from these services.

The participants mentioned the following difficulties in dealing with cases of marital violence: the woman's silence, the difficulty of coordinating their activities with some network services, the counter-reference, and the lack of professional training.

It is necessary to think about the expansion of educational practices, as well as to reformulate actions, deepening the knowledge of the health care team members by doing qualified training. Currently, little research relating theory and practice has been conducted on the subject.

FHS teams deal with marital violence often because they work directly with people and their way of life. The lack of training seems to potentialize the feelings of fear, anguish and impotence, which compromises the professional practice. Also, lack of training, which results in inadequate or ineffective actions, harms the health of women suffering violence.

It should be noted that this study does not cover all the possibilities of analyzing this problem. Other analytical perspectives and contributions to the improvement of health care and assistance for women suffering marital violence are possible and necessary.

It is hoped that the results found in this study and the reflection on the subject can contribute to advancing the knowledge about the complex problem of marital violence, stimulating the adoption of more effective management, assistance, and care actions and the resignification of existing actions in order to guarantee the integral care for these women.

\section{REFERENCES}

1. Teles MAA, Melo M. O que é violência contra a mulher. $1^{\text {a }}$ ed. eBook. São Paulo: Brasiliense; 2017.

2. Waiselfisz JJ. Mapa da Violência 2015: homicídios de mulheres no Brasil. Brasília (DF): Organização Pan-Americana da Saúde. Organização Mundial da Saúde. Secretaria Especial de Políticas para as Mulheres. Ministério das Mulheres, da Igualdade Racial e dos Direitos Humanos. Faculdade Latino-Americana de Ciências Sociais; 2015. Available from: http://www.mapadaviolencia.org.br

3. Senado Federal. Brasil. Panorama da violência contra as mulheres no Brasil indicadores nacionais e estaduais. Brasília: Senado Federal; 2016. 
4. Santos FPA, Acioli S, Rodrigues VP, Machado JC, Souza MS, Couto TA Nurse care practices in the Family Health Strategy. Rev Bras Enferm. 2016; 69(6): 1060-7. Available from: http://dx.doi.org/10.1590/00347167-2016-0273

5. Sousa AR, Pereira Á, Paixão GPN, Pereira NG, Campos LM, Couto TM. Repercussões da prisão por violência conjugal: o discurso de homens. Rev Latino-Am Enfermagem. 2016; 24: e2847. Available from: http://dx.doi.org/10.1590/1518-8345.1569.2847

6. Carneiro JB, Gomes NP, Estrela FM, Santana JD, Mota RS, Erdmann AL. Violência conjugal: repercussões para mulheres e filhas(os). Esc Anna Nery. 2017; 21(4): e20160346. Available from: http://dx.doi. org/10.1590/2177-9465-ean-2016-0346

7. Bardin L. Análise de conteúdo. São Paulo: Edições 70; 2011.

8. Brasil. Ministério da Saúde. Política Nacional de Humanização do SUS. Brasília: Editora do Ministério da Saúde; 2013 . Available from: http://bvsms.saude.gov.br/bvs/publicacoes/politica_nacional_ humanizacao_pnh_folheto.pdf

9. Broch D, Gomes VLO, Silva CD, Gomes GC, Abreu DPG, Mattos MB. Violência conjugal contra a mulher: representações sociais de Agentes Comunitários de Saúde. Rev Enferm UFPE On Line. 2016 10(10): 3743-50. Available from: https://periodicos.ufpe.br/revistas/ revistaenfermagem/article/view/11439

10. Silva EB, Padoin SMM, Vianna LAC. Mulher em situação de violência: limites da assistência. Ciênc saúde coletiva . 2015 20(1):249-58. Available from: http://dx.doi.org/10.1590/141381232014201.21202013

11. Cela M, Oliveira IF. O psicólogo no Núcleo de Apoio à Saúde da Família: articulação de saberes e ações. Estud Psicol . 2015 ; 20(1):319. Available from: http://www.scielo.br/pdf/epsic/v20n1/1413-294Xepsic-20-01-0031.pdf

12. Vieira LB, Padoin SMM, Souza IEO, Paula CC, Terra MG. Necessidades assistenciais de mulheres que denunciam na delegacia de polícia a vivência da violência. Aquichan. 2013; 13(2): 197-205. Available from: http://www.scielo.org.co/scielo.php?script=sci_arttext\&pid=S165759972013000200006\&lng=en\&nrm=iso\&tlng=pt

13. Vieira LB, Padoin SMM, Souza IEO, Paula CC. Perspectivas para o cuidado de enfermagem às mulheres que denunciam a violência vivida. Esc Anna Nery. 2011; 15(4): 678-85. Available from: http:// dx.doi.org/10.1590/S1414-81452011000400004

14. Gomes NP, Erdmann AL, Mota LL, Carneiro JB, Andrade SR, Koerich C. Encaminhamentos à mulher em situação de violência conjugal. O Mundo da Saúde. 2013; 377(4): 377-84. Available from: http:// bvsms.saude.gov.br/bvs/artigos/mundo_saude/encaminhamentos_ mulher_situacao_violencia_conjugal.pdf

15. Cortes LF, Padoin SMM, Kinalski DDF. Instrumentos para articulação da rede de atenção às mulheres em situação de violência: construção coletiva. Rev Gaúcha Enferm. 2016; 37 (spe). Available from: http:// dx.doi.org/10.1590/1983-1447.2016.esp.2016-0056

16. Souza LPS, Souza AG, Figueiredo T, Brito MFSG, Leite MTSL, Souza KV. Violência de gênero: o silêncio e enfrentamento vivido pelas mulheres à luz da fenomenologia social. Rev Enferm UFPE On Line. 2016 ; 10(10): 3842-50. Available from: https://periodicos.ufpe.br/ revistas/revistaenfermagem/article/view/11451

17. Santos MS, Silva JG, Branco JGO. O enfrentamento à violência no âmbito da estratégia saúde da família: desafios para a atenção em saúde. Rev Bras Promoç Saúde. 2017; 30(2): 229-38. Available from: http://periodicos.unifor.br/RBPS/article/view/5895

18. Moreira TNF, Martins CL, Feuerwerker LCM, Schraiber LB. A construção do cuidado: o atendimento às situações de violência conjugal por equipes de Saúde da Família. Saude soc. 2014 23(3): 814-27. Available from: http://dx.doi.org/10.1590/S010412902014000300007

19. Cordeiro KCC, Santos RM, Gomes NP, Melo DS, Mota RS, Couto TM. Formação profissional e notificação da violência contra a mulher Revista Baiana de Enfermagem. 2015; 29(3): 209-17. Available from: http://dx.doi.org/10.18471/rbe.v29i3.13029

Received in: 06/06/2018

Required revisions: 13/12/2018

Approved in: $15 / 02 / 2019$

Published in: 01/07/2020

Corresponding author

Vanda Palmarella Rodrigues

Address: Av. José Moreira Sobrinho, s/n, Jequiezinho Jequié/BA, Brazil

Zip code: $45.205-490$

Email address: vprodrigues@uesb.edu.br Telephone number: +55 (73) 3528-9607 